\title{
Meningkatkan Kompetensi guru dalam penyusunan RPP Yang Baik Dan Benar Melalui Pendampingan Berbasis MGMP Semester ganjil Tahun Pelajaran 2017/2018 SMP Negeri 1 Ambalawi
}

\author{
Rusdi Abdullah \\ Kepala SMP Negeri 1 Ambalawi.
}

\begin{abstract}
Abstrak; Latar belakang diadakannya Penelitian ini adalah rendahnya kompetensi guru sasaran Di SMP Negeri 1 Ambalawi dalam penyusunan Rencana Pelakssanaan Pembelajaran (RPP) yang baik dan benar yang berdampak kurang percaya diri dalam proses pembelajaran. Solusinya diadakan pendampingan baik secara kelompok maupun individu dalam penyusunan RPP yang baik dan benar. Tujuannya adalah untuk mengetahui efektifitas pelaksanaan pendampingan berbasis MGMP dalam upaya meningkatkan kompetensi guru dalam menyusun RPP yang baik dan benar, yang bermanfaat untuk meningkatkan profesionalisme sebagai Kepala Sekolah dan bagi guru untuk meningkatkan proses pembelajaran di kelas. Hipotesis tindakan: meningkatkan kompetensi guru guru sasaran SMP Negeri 1 Ambalawi semester ganjil tahun pelajaran 2017/2018 dalam menyusun RPP yang baik dan benar. Penelitian ini dilaksanakan sebanyak dua siklus, masing-masing siklus dua kali pertemuan. Tahapan setiap siklus adalah perencanaan, pelaksanaan, pengamatan, dan refleksi. Indikator keberhasilan dalam penelitian ini adalah; 1) hasil observasi Kepala Sekolah maupun observasi guru selama proses pendampingan telah memperoleh skor rata-rata $\geq 4,0,2$ ) hasil kerja guru dalam penyusunan RPP mencapai $\geq$ $85 \%$ dengan nilai rata-rata $\geq 80,00$. Hasil penelitian pada siklus I observasi Kepala Sekolah ratarata $(3,30)$, observasi guru rata-rata $(3,10)$ dan hasil kerja individual rata-rata nilai $(69,37)$ dengan prosentase ketercapaian (0\%). Pada siklus II observasi Kepala Sekolah rata-rata $(4,30)$, observasi guru rata-rata $(4,20)$ dan hasil kerja individual rata-rata nilai $(86,29)$ dengan prosentase ketercapaian (100\%). Indikator keberhasilan telah tercapai, penelitian di nyatakan berhasil dan dihentikan pada siklus II. Kesimpulan; pelaksanaan pendampingan dapat meningkatkan kompetensi guru sasaran SMP Negeri 1 Ambalawi dalam penyusunan RPP yang baik dan benar. Disarankan agar Kepala Sekolah lainnya melakukan penelitian sejenis dalam upaya peningkatan kompetensi guru, dan kepada guru mata pelajaran agar mampu menyusun RPP dengan baik dan benar.
\end{abstract}

Kata Kunci : Kompetensi guru, Pendampingan RPP, MGMP.

\section{PENDAHULUAN}

Pada hakikatnya penyusunan

Rencana Pelaksanaan Pembelajaran (RPP) bertujuan merancang pengalaman belajar peserta didik untuk mencapai tujuan pembelajaran. Tidak ada alur pikir yang spesifik untuk menyusun RPP, karena rancangan tersebut seharusnya kaya akan inovasi sesuai dengan spesifikasi materi ajar dan lingkungan belajar peserta didik yang meliputi sumber daya alam dan sumber daya lokal, kebutuhan masyarakat, serta perkembangan ilmu pengetahuan dan teknologi. Rencana Pelaksanaan Pembelajaran (RPP) yang dibuat oleh guru selama ini diduga guru tidak melakukan penghayatan terhadap jiwa profesi pendidik. Keadaan ini dapat dipahami karena, guru terbiasa menerima barang-barang dalam bentuk format yang mengekang guru untuk berinovasi dalam penyiapan RPP yang cenderung bersifat formalitas. Bukan menjadi komponen utama untuk sebagai acuan dalam proses pembelajaran, sehingga 
ketika otonomi pendidikan dilayangkan tak seorang gurupun mempercayainya.

Kondisi nyata yang terjadi di SMP Negeri 1 Ambalawi bahwa pada umumnya guru memiliki RPP bukan buatan sendiri, kecendrungan: 1) meminjam dari guru sekolah lain yang kondisi peserta didiknya tidak setara, sehingga RPP tidak tepat untuk dilakukan di sekolah, 2) copy paste dari internet walaupun isinya tidak sesuai dsengan tata cara penyusunan RPP yang baik dan benar, 3) menggunakan RPP yang berasal dari LKS, terbitan swasta yang kurang dapat dipertanggung jawabkan.

Faktor penyebabnya adalah: 1) guru belum pernah mendapatkan bimbingan secara khusus bagaimana menyusun RPP yang baik dan benar dari Kepala Sekolah, 2) setiap guru mengajukan RPP untuk disyahkan oleh Kepala Sekolah tidak pernah disalahkan dan langsung ditanda tangani, 3) guru belum pernah mengikuti pendidikan dan pelatihan (Diklat) tentang penyusunan RPP yang baik dan benar, kalaupun ada yang pernah mengikuti kegiatannya kurang serius, di jadwalkan 5 (lima) hari kerja baru tiga hari sudah ditutup, 4) alasan klasik guru beralasan jumlah jam mengajarnya banyak sehingga tidak sempat untuk menyusun RPP, prinsipnya yang penting mengajar di kelas dengan berpedoman dengan buku paket siswa yang sudah disediakan oleh pihak sekolah dan oleh peserta didik itu sendiri.

Sebenarnya banyak solusi yang dapat dilakukan oleh Kepala Sekolah selaku peneliti, antara lain: 1) diadakan bimbingan/pendampingan khusus bagi guru sasaran, 2) diadakan bintek khusus penyusunan RPP yang baik dan benar, 3) di galakkan pelaksanaan Musyawarah Guru Mata Pelajaran (MGMP), dan lain-lain. Dalam penelitian ini Kepala Sekolah memilih melakukan pendampingan bagi 10 (sepuluh) guru sasaran melalui wadah MGMP dalam upaya meningkatkan kompetensi guru menyusun RPP yang baik dan benar, semester ganjil Tahun Pelajaran 2017/2018 yang di pusatkan di SMP Negeri 1 Ambalawi. Ada beberapa keunggulan pelaksanaan sistem pendampingan berbasis MGMP yakni: 1) melatih keberanian guru untuk berpendapat terhadap sesama guru, 2) pekerjaan yang berat bisa menjadi ringan, 3) menambah nilai kekeluargaan, kebersamaan, dan jiwa saling menolong, 4) bisa mengemukakan ide, gagasan, serta etos kerja yang berkualitas, dan 5) bisa merubah mindset guru dalam perencanaan proses pembelajaran dan sistem penilaian. Berdasarkan beberapa keunggulan dari proses pendampingan berbasis MGMP, peneliti meyakini rendahnya kompetensi guru dalam penyusunan RPP yang baik dan benar dapat diminimalkan dan bahkan mampu meningkatkan kualitas proses dan hasil belajar peserta didik di kelas senyatanya.

\section{KAJIAN PUSTAKA \\ Kompetensi Guru}

Guru adalah pendidik profesional dengan tugas utama mendidik, mengajar, membimbing, mengarahkan, melatih, menilai, dan mengevaluasi peserta didik pada pendidikan anak usia dini jalur pendidikan formal, pendidikan dasar, dan menengah (Undang-Undang RI Nomor 14 Tahun 2005 Tentang Guru dan Dosen). Guru merupakan seseorang yang mempunyai tugas mulia untuk mendorong, membimbing dan memberi fasilitas belajar bagi siswa untuk mencapai tujuan. Guru mempunyai tanggung jawab untuk melihat segala sesuatu yang terjadi dalam kelas untuk membantu proses perkembangan siswa. Penyampaian materi pelajaran hanyalah merupakan salah satu dari berbagai kegiatan dalam belajar sebagai suatu proses yang dinamis dalam segala fase dan proses perkembangan siswa (Slameto, 2003: 97).

Kompetensi Guru; Kompetensi profesional guru menurut Sudjana (2002 : 17-19) dapat dikelompokkan menjadi tiga bidang yaitu pedagogik, personal dan sosial. 
Kompetensi pedagogik menyangkut kemampuan intelektual seperti penguasaan mata pelajaran, pengetahuan menganai cara mengajar, pengetahuan mengenai belajar dan tingkah laku individu, pegetahuan tentang bimbingan penyuluhan, pengetahuan tentang administrasi kelas, pengetahuan tentang cara menilai hasil belajar, pengetahuan tentang kemasyarakatan serta pengetahuan umum lainnya.

Berdasarkan Peraturan Pemerintah Nomor 19 Tahun 2005 tentang Standar Nasional Pendidikan, guru harus memiliki kompetensi pedagogik, kepribadian, profesional, dan sosial (Depdiknas, 2005 : 24, 90-91).

1. Kompetensi pedagogik merupakan kemampuan yang berkenaan dengan pemahaman peserta didik dan pengelola pembelajaran yang mendidik dan dialogis. Secara substantif kompetensi ini mencakup kemampuan pemahaman terhadap peserta didik, perancangan dan pelaksanaan pembelajaran, evaluasi hasil belajar, dan pengembangan peserta didik untuk mengaktualisasikan berbagai potensi yang dimilikinya.

2. Kompetensi kepribadian merupakan kemampuan personal yang mencerminkan kepribadian yang mantap, arif, dewasa, dan berwibawa, menjadi teladan bagi peserta didik, dan berakhlak mulia.

3. Kompetensi profesional merupakan kemampuan yang berkenaan dengan penguasaan materi pembelajaran bidang studi secara luas dap mendalam yang mencakup penguasaan substansi isi materi kurikulum matapelajaran di sekolah dan substansi keilmuan yang menaungi materi kurikulum tersebut, serta menambah wawasan keilmuan sebagai guru.

4. Kompetensi sosial berkenaan dengan kemampuan pendidik sebagai bagian dari masyarakat untuk berkomunikasi dan bergaul secara efektif dengan peserta didik, sesama pendidik, tenaga kependidikan, orangtua/wali peserta didik, dan masyarakat sekitar.

Yang dimaksud dengan kompetensi guru dalam penelitian tindakan sekolah (PTS) ini adalah kemampuan 10 (sepuluh) guru sasaran dalam penyusunan Rencana Pelaksanaan Pembelajaran (RPP) yang baik dan benar. Adapaun ciri-ciri RPP dikatakan baik dan benar adalah: 1) memuat aktifitas proses belajar mengajar yang akan dilaksanakan oleh guru dan menjadi pengalaman belajar bagi peserta didik, 2) langkah-langkah pembelajaran disusun secara sistematis agar tujuan pembelajaran dapat dicapai, 3) langkah-langkah pembelajaran disusun serinci mungkin, sehingga apabila RPP digunakan guru lain (misalnya, ketiga guru mata pelajaran tidak hadir) mudah dipahami dan tidak menimbulkan penafsiran ganda.

\section{Pendampingan}

Pendampingan adalah sebuah bentuk hubungan yang memungkinkan terjadinya proses berbagi keterampilan dan pengalaman baik professional, maupun personal yang mendorong proses tumbuh dan berkembang sepanjang proses yang terjadi. Pendampingan merupakan bentuk hubungan antar personal antara seseorang yang dipandang lebih berpengalaman atau lebih professional dan seseorang yang diposisikan masih kurang berpengalaman atau kurang professional. Proses pendampingan didasarkan pada pemberian dorongan, komentar dan saran yang bersifat membangun, terlaksana dalam suasana keterbukaan, saling percaya dan saling menghargai, serta keinginan yang kuat untuk berbagi dan belajar satu sama lain. Keseluruhan proses dan semua aspek pendampingan terjadi karena hubungan yang terjalin antara pihak yang terlibat dalam pendampingan adalah hubungan yang sudah lama terbangun.

Pada dasarnya, konsep mentoring mencakup tiga komponen, yaitu: 
pendamping, yang terdampingi, dan proses pendampingan. Pendamping bisa seorang guru, sponsor, konselor, penasehat, teman sejawat, pendukung, orang kepercayaan, atau model. Yang terdampingi biasanya adalah seseorang yang masih pemula dan digambarkan sebagai mitra peserta dalam proses pendampingan. Proses pendampingan adalah pengembangan hubungan antara pendamping dan yang terdampingi. Definisi pendampingan sangat beragam tergantung pada strategi yang digunakan. Secara umum, pendampingan adalah proses yang melibatkan seseorang yang lebih berpengalaman, profesional, pakar untuk memberikan dukungan, bimbingan, dan nasehat kepada, serta berbagi pengalaman dengan rekan yang kurang berpengalaman.

Dalam wujudnya yang paling efektif, pendampingan adalah kemitraan pembelajaran yang melibatkan kerjasama dan peluang untuk menghadapi tantangan dan melakukan refleksi berkelanjutan oleh kedua belah pihak yang terlibat. Hubungan pendampingan bisa juga berupa kemitraan sejawat yang di dalamnya, posisi dan peran pendamping dan yang terdampingi bisa saja bertukar berdasarkan konteks tertentu.

Yang dimaksud dengan pendampingan dalam penelitian tindakan sekolah (PTS) ini adalah kepala SMP Negeri 1 Ambalawi selaku peneliti membimbing/mendampingi terhadap 10 (sepuluh) guru sasaran dalam penyusunan RPP yang baik dan benar. Dalam pelaksanaannya pendampingan dilakukan melalui 2 (dua) tahapan. Tahap I semua guru dikumpulkan untuk mendapatkan penjelasan teknik tata cara penyusunan RPP yang baik dan benar sesuai dengan bidang studi/mata pelajaran yang diampunya. Tahap II yaitu pendampingan individual, dimana peneliti mendampingi secara individu dalam kelompok kecil untuk menjelaskan lebih rinci tata cara menyusun RPP yang baik dan benar.

\section{MGMP}

Musyawarah Guru Mata Pelajaran sama halnya dengan $\mathrm{KKG}$, merupakan suatu organisasi guru yang dibentuk untuk menjadi forum komunikasi yang bertujuan untuk memecahkan masalah yang dihadapi guru dalam pelaksanaan tugasnya sehari-hari di lapangan. MGMP berada di tingkat sekolah lanjutan, baik SLTP maupun SLTA. Musyawah Guru Mata Pelajaran, awalnya disebut Musyawarah Guru Bidang Studi, adalah suatu organisasi profesi guru yang bersifat non struktural yang dibentuk oleh guru-guru di Sekolah Menengah (SLTP atau SLTA) di suatu wilayah sebagai wahana untuk saling bertukaran pengalaman guna meningkatkan kemampuan guru dan memperbaiki kualitas pembelajaran.

Selain ditingkat komisariat, MGMP pun memilki wadah yang lebih luas ditingkat kabupaten atau kota. Hal ini untuk lebih mencakup permasalahan-permasalahan yang ada pada guru secara meluas sehingga kesenjangan yang ada pada guru lebih kecil, dan mereka dapat lebih mengetahui permasalahan dan solusinya dari hasil pertemuan kelompok kerja tersebut secara menyeluruh. Bagaimana eksistensi,peranan,dan kinerja MGMP sesudah meraih legalitas dari pemerintah daerah?.Yang pasti pada saat MGMP tidak akan lagi dihadang oleh hambatan birokratis seperti yang pernah terjadi,karena sudah mengantongi legitimasi dari pemerintah daerah bahkan dari Pemerintah Pusat.Namun peranan dan kinerja MGMP masih harus ditunggu eksistensinya.Paling tidak setumpuk asa yang dicurahkan kepada wadah profesionalisme guru di tinkat SMP, SMA, dan SMK dalam upaya peningkatan kualitas pendidikan di tingkat menengah.

Sebagaimana kita ketahui, MGMP merupakan forum atau wadah profesionalisme guru maa pelajaran yang berada pada suatu wilayah kabupaten/kota/ kecamatan/sanggar/gugus sekolah. Ruang lingkupnya meliputi guru mata pelajaran pada tingkat SMP, SMA, dan SMK Negeri 
dan Swasta,baik yang berstatus PNS maupun swasta. Prinsip kerjanya adalah cerminan kegiatan "dari, oleh, dan untuk guru" dari semua sekolah. Atas dasar ini,maka MGMP merupakan organisasi nonstruktural yang bersifat mandiri,berasaskan kekeluargaan,dan tidak mempunyai hubungan hierarkis dengan lembaga lain.

Dalam hal ini adapun tujuan diselenggarakanya MGMP, yaitu:

1. Untuk memotivasi guru guna meningkatkan kemampuan dan keterampilan dalam merncanakan,melaksanakan,dan membuat evaluasi program pembelajaran dalam rangka meningkatkan keyakinan diri sebgai guru profesional;

2. Untuk meningkatkan kemampuan dan kemahiran guru dalam melaksanakan pembelajaran sehingga dapat menunjang usaha peningkatan dan pemerataan mutu pendidikan;

3. Untuk mendiskusikan permasalahan yang dihadapi dan dialami oleh guru dalam melaksanakan tugas sehariharidan mencari solusi alternatif pemecahanya sesuai dengan karakteristik mata pelajaran masingmasing,guru,kondisi sekolah,dan lingkunganya;

4. Untuk membantu guru memperoleh informasi teknis edukatif yang berkaitan dengan kegiatan ilmu pengetahuan dan teknologi,kegiatan

kurikulum,metodologi,dan sistem pengujian yang sesuai dengan mata pelajaran yang bersangkutan;

5. Untuk saling berbagi informasi dan pengalaman dari hasil lokakarya,simposium,seminar,diklat,clas sroom action research,referensi,dan lainlain kegiatan profesional yang di bahas bersama-sama.

\section{Rencana Pelaksanaan Pembelajaran (RPP)}

Jurnal Ilmiah Mandala Education
Pada hakekatnya penyusunan RPP bertujuan merancang pengalaman belajar siswa untuk mencapai tujuan pembelajaran. Tidak ada alur pikir (algoritma) yang spesifik untuk menyusun suatu RPP, karena rancangan tersebut seharusnya kaya akan inovasi sesuai dengan spesifikasi materi ajar dan lingkungan belajar siswa (sumber daya alam dan budaya lokal, kebutuhan masyarakat serta perkembangan ilmu pengetahuan dan teknologi). Pengalaman dari penilaian portofolio sertifikasi guru ditemukan, bahwa pada umumnya RPP guru cenderung bersifat rutinitas dan kering akan inovasi. Mengapa? diduga dalam melakukan penyusunan RPP guru tidak melakukan penghayatan terhadap jiwa profesi pendidik. Keadaan ini dapat dipahami karena, guru terbiasa menerima borang-borang dalam bentuk format yang mengekang guru untuk berinovasi dan penyiapan RPP cenderung bersifat formalitas. Bukan menjadi komponen utama untuk sebagai acuan kegiatan pembelajaran. Sehingga ketika otonomi pendidikan dilayangkan tak seorang gurupun bisa mempercayainya. Buktinya perilaku menyusun RPP dan perilaku mengajar guru tidak berubah jauh.

Acuan alur pikir yang dapat digunakan sebagai alternatif adalah:

1. Kompetensi apa yang akan dicapai.

2. Indikator-indikator yang dapat menunjukkan hasil belajar dalam bentuk perilaku yang menggambarkan pencapaian kompetensi dasar.

3. Tujuan pembelajaran yang merupakan bentuk perilaku terukur dari setiap indikator.

4. Materi dan uraian materi yang sesuai dengan kebutuhan belajar siswa agar ianya dapat mencapai tujuan pembelajaran.

5. Metode-metode yang akan digunakan dalam pembelajaran.

6. Langkah-langkah penerapan metodemetode yang dipilih dalam satu kemasan pengalaman belajar. 
7. Sumber dan media belajar yang terkait dengan aktivitas pengalaman belajar siswa.

8. Penilaian yang sesuai untuk mengukur ketercapaian tujuan pembelajaran.

Secara umum, ciri-ciri Rencana Pelaksanaan Pembelajaran (RPP) yang baik adalah sebagai berikut: 1) Memuat aktivitas proses belajar mengajar yang akan dilaksanakan oleh guru yang akan menjadi pengalaman belajar bagi siswa, 2) Langkahlangkah pembelajaran disusun secara sistematis agar tujuan pembelajaran dapat dicapai. 3) Langkah-langkah pembelajaran disusun serinci mungkin, sehingga apabila RPP digunakan oleh guru lain (misalnya, ketiga guru mata pelajaran tidak hadir), mudah dipahami dan tidak menimbulkan penafsiran ganda.

\section{Kerangka Konseptual}

Variabel harapan dalam penilaian ini adalah meningkatnya kompetensi 10 (sepuluh) guru sasaran dalam penyusunan RPP yang baik dan benar, sedangkan variabel tindakan dalam penelitian iniadalah melaksanakan pendampingan secara klasikal (kelompok besar) dan pendampingan individual (kelompok kecil/perorangan) berbasis MGMP.

\section{METODE PENELITIAN}

Penelitian Tindakan Sekolah (PTS) ini dilaksanakan di SMP Negeri 1 Ambalawi yang pelaksanaannya melalui kegiatan pendampingan berbasis MGMP bagi 10 (sepuluh) guru sasaran dalam penyusunan RPP yang baik dan benar yang dilaksanakan dalam forum MGMP sekolah .

- Jenis Tindakan : pendampingan berbasis MGMP dalam penyusunan RPP yang baik dan benar bagi 10 (sepuluh) guru sasaran di SMP Negeri 1 Ambalawi semester ganjil Tahun Pelajaran 2017/2018

- Dampak yang diharapkan :

Meningkatnya kompetensi 10 (sepuluh) guru sasaran dalam penyusunan RPP yang baik dan benar.

\section{Perencanaan Tindakan}

\section{Jenis tindakan yang dilakukan}

1. Kepala Sekolah menginformasikan hasil pantauan, supervisi administrasi terhadap 10 (sepuluh) guru sasaran bahwa guru-guru dimaksud masih belum mampu/mengalami kendala/hambatan-hambatan dalam penyusunan RPP yang baik dan benar.

2. Kepala Sekolah menyampaikan perlunya diadakan pendampingan berbasis MGMP bagi guru sasaran dalam penyusunan RPP yang baik dan benar

3. Kepala Sekolah menyampaikan materi pendampingan sesuai dengan skenario pelaksanaan pendampingan berbasis MGMP. Untuk mendapatkan gambaran riil tentang skenario pelaksanaan tindakan pada kegiatan pendampingan berbasis MGMP ini dapat di gambarkan sebagai berikut:

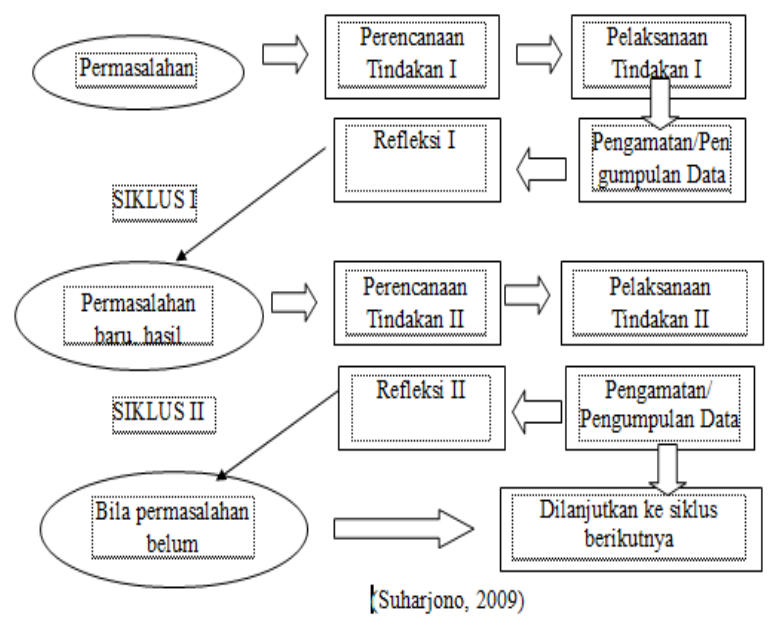

\section{Pelaksanaan Tindakan}

Adapun jenis instrumen yang digunakan dalam penelitian ini sebagai berikut:

1. Instrumen pengamatan/observasi Kepala Sekolah dilakukan oleh observer (pengawas selaku pembimbing)

2. Instrumen pengamatan/observasi guru peserta pendampingan dilakukan oleh peneliti (Kepala Sekolah) 
3. Instrumen penilaian hasil kerja individual dalam penyusunan RPP yang baik dan benar dilakukan oleh peneliti, ini sekaligus merupakan tolak ukur berhasil tidaknya dalam penyusunan RPP melalui pendampingan berbasis MGMP sesuai dengan indikator keberhasilan yang telah di tetapkan.

\section{Evaluasi dan Refleksi Tindakan}

Pada tahapan ini peneliti melakukan kajian dan penelitian proses tindakan dan hasil atau dampak tindakan terhadap perubahan perilaku sasaran (nana Sujana, 2009:39). Adapun kegiatan riilnya adalah: 1) membandingkan hasil pengamatan pelaksanaan kerja kelompok/diskusi yang difokuskan kegiatan penyusunan RPP yang baik dan benar berdasarkan kurikulum 2007, 2) membandingkan hasil kerja individual dari 10 (sepuluh) guru sasaran dalam penyusunan RPP dengan indikator keberhasilan yang telah ditetapkan.

\section{Siklus Tindakan}

Dalam penelitian ini di rencanakan sebanyak 2 (dua) siklus, masing-masing siklus 1 (satu) kali pertemuan dengan agenda 2 (dua) kegiatan secara terpadu yaitu pendampingan klasikal/kelompok besar dan pendampingan individual/kelompok kecil. Kegiatan masing-masing siklus terdiri dari 4 (empat) tahapan yaitu perencanaan, pelaksanaan, observasi, dan refleksi. Untuk mendapatkan gambaran secara rinci kegiatan masing-masing tahapan dapat di jelaskan sebagai berikut:

\section{SIKLUS I}

\section{Tahap I : Perencanaan Tindakan}

1.1. Menyusun materi pendampingan

1.2. Menetapkan scenario dan langkahlangkah pendampingan yang tertuang dalam Rencana Pelaksanaan pendampingan (RPP)

1.3. Menyusun instrument observasi Kepala Sekolah dan observasi guru
1.4. Menentukan jadwal kegiatan pendampingan

1.5. Menyusun pedoman analisa data hasil observasi dan tugas individu.

\section{Tahap II. Pelaksanaan Tindakan}

Pada kegiatan pendampingan secara

berkelompok yang kegiatannya adalah :

2.1. Menyampaikan materi tentang tata cara penyusunan RPP yang baik dan benar.

2.2. Melaksanakan diskusi kelompok kecil dalam penyusunan RPP.

2.3. Memberikan bimbingan secara berkelompok/perorangan.

2.4. Memberikan solusi terhadap permasalahan yang dihadapi oleh guru

2.5. Memberikan penguatan/reward

2.6. Memberikan tugas individual.

Pada kegiatan pendampingan individual yang dilakukan secara bergiliran, dengan cara peneliti mendekati guru satu persatu dalam kelompok untuk membimbing secara individual agar permasalahanppermasalahan dapat dipecahkan dengan baik dan benar.

Tahap III. Observasi/pengumpulan Data

3.1. Pengamatan terhadap aktifitas guru peserta pendampingan

3.2. Pengamatan terhadap kinerja guru dalam penyusunan RPP yang baik dan benar.

3.3. Menilai hasil kerja guru secara individual

Tahap IV. Refleksi

4.1. Renungan atas data hasil observasi dan hasil kerja secara individual.

4.2. Pengolahan data hasil penelitian dan mencocokkan dengan indikator keberhasilan.

4.3. Rencana perbaikan dan penyempurnaan 4.4. Memberikan penguatan atas hasil yang diperolehnya.

4.5. Rencana tindak lanjut.

\section{SIKLUS II}

Jenis kegiatan pada siklus II ini pada dasarnya sama dengan siklus I, bedanya hanya terjadi perbaikan/penyempurnaan dalam pelaksanaannya. 
Indikator Keberhasilan

1. Hasil observasi Kepala Sekolah maupun observasi guru peserta pendampingan telah mencapai skor rata-rata $\geq 4,0$ (Kategori baik).

2. Hasil kerja secara individual penyusunan RPP yang baik dan benar berdasarkan kurikulum 2007 dinyatakan telah berhasil jika mencapai $\geq 85 \%$ dengan nilai rata-rata $\geq 80,00$ (Kategori Baik).

\section{HASIL PENELITIAN}

\section{Deskripsi Siklus I}

\section{Tahap Perencanaan}

Pada tahapan ini peneliti melakukan:

1) menyusun materi pendampingan, 2) menetapkan skenario dan langkah-langkah pendampingan yang tertuang dalam Rencana Pelaksanaan Pendampingan (RPP), 3) menyusun instrumen observasi Kepala Sekolah dan instrumen observasi guru, 4) menentukan jadwal kegiatan pendampingan, 5) menyusun pedoman analisis data.

\section{Tahap Pelaksanaan}

Pada tahapan ini peneliti melakukan pendampingan secara klasikal maupun pendampingan secara individual, dengan rincian kegiatan sebagai berikut:

- Pendampingan klasikal/kelompok; 1) menyampaikan materi tentang tata cara penyusunan RPP yang baik dan benar, 2) melaksanakan diskusi kelompok kecil dalam penyusunan RPP, 3) memberikan bimbingan secara berkelompok, 4) memberikan solusi terhadap permasalahan yang dihadapi oleh guru, 5) memberikan penguatan/reward, dan 6) memberikan tugas individual.

- Pendampingan individual, jenis kegiatannya adalah; 1) pada saat guru bekerja dalam kelompok/diskusi kelompok peneliti membimbing guru yang mengalami kesulitan dalam penyusunan RPP secara kelompok kecil/perorangan, 2) memberikan solusi/pemecahan terhadap kesulitan yang dirasakan secara individual, 3) kegiatan seterusnya sampai ke 10 (sepuluh) guru peserta pendampingan mendapatkan giliran pendampingan secara individual

\section{Tahap Observasi}

Pada saat proses pendampingan peneliti mendapatkan data hasil pengamatan terhadap kegiatan Kepala Sekolah oleh observer yang memperoleh skor rata-rata sebesar 3,30, data hasil observasi guru memperoleh skor rata-rata sebesar 3,10 dan data hasil akhir hasil kerja individual dalam penyusunan RPP yang baik dan benar memperoleh nilai rata-rata sebesar 69,37.

\section{d. Tahap Refleksi}

Pada tahapan ini peneliti merenung atas perolehan data hasil observasi Kepala Sekolah, observasi guru, dan nilai individual hasil penyusunan RPP yang baik dan benar. Selanjutnya peneliti mengolah data dan hasilnya di cocokkan dengan indikator keberhasilan dengan rincian sebagai berikut: Hasil Observasi Kepala Sekolah $(3,30)$, Hasil Observasi Guru $(3,10)$, dan Rata-rata Nilai Individual $(69,37)$.

Karena perolehan hasil masih dibawah indikator keberhasilan yang direncanakan, maka pada siklus berikutnya akan diadakan perbaikan dan penyempurnaan dari serangkaian kegiatan pendampingan secara klasikal maupun secara individual, namun demikian peneliti tetap memberikan penguatan atas hasil yang diperolehnya dan penelitian dilanjutkan pada siklus II dengan mengoptimalkan semua jenis tindakan dalam pendampingan sehingga di peroleh hasil yang memuaskan.

\section{Deskripsi Siklus II}

\section{Tahap Perencanaan}

Tahapan perencanaan pada siklus II jenis kegiatannya masih sama dengan siklus I, bedanya pada siklus II ini lebih memfokuskan perbaikan/penyempurnaan dalam proses pendampingan klasikal maupun pendampingan individual, yang jenis kegiatannya adalah: 1) menyempurnakan materi pendampingan, 2) 
menetapkan skenario pendampingan, 3) menetapkan instrumen observasi Kepala Sekolah maupun observasi guru, 4) menetapkan jadwal kegiatan pendampingan, 5) menyusun pedoman analisis data hasil observasi dan tugaas individu

\section{Tahap Pelaksanaan}

- Pendampingan klasikal/kelompok; 1)menyampaikan/merefleksi hasil perolehan data pada siklus I, 2) menjelaskan ulang tata cara penyusunan RPP yang baik dan benar secara lebih rinci, 3) perbaikan RPP secara berkelompok/diskusi kelompok, 4) memberikan refleksi terhadap hasil kerja kelompok yang mengalami kendala, 5) memberikan penghargaan/reward dan 6) memberikan tugas individual.

- Pendampingan individual/kelompok kecil; 1) pada saat proses kerjasama dalam kelompok, peneliti mengamati/mencermati hasil kerja secara individual, 2) memberikan bimbingan/merefleksi terhadap hasil kerja individual yang masih mengalami kendala, 3) begitu seterusnya sampai semua guru peserta pendampingan mendapatkan pendampingan secara individual.

\section{Tahap Observasi/Pengumpulan Data}

Pada saat proses pendampingan peneliti mendapatkan data hasil pengamatan terhadap kegiatan Kepala Sekolah oleh observer yang memperoleh skor rata-rata sebesar 4,30, data hasil observasi guru memperoleh skor rata-rata sebesar 4,20 dan data hasil akhir hasil kerja individual dalam penyusunan RPP yang baik dan benar memperoleh nilai rata-rata sebesar 86,29.

\section{Tahap Refleksi}

Pada tahapan ini peneliti merenung atas perolehan data hasil observasi Kepala Sekolah, observasi guru, dan nilai individual hasil penyusunan RPP yang baik dan benar. Kemudian di olah engan menggunakan rumus yang telah ditetapkan. Hasil perolehan data di cocokkan dengan indikator keberhasilan dengan perolehan data sebagai berikut: Hasil Observasi Kepala Sekolah (4,30), Hasil Observasi Guru (4,20), dan Rata-rata Nilai Individual $(86,29)$

Karena perolehan hasil siklus II sudah melebihi indikator keberhasilan, maka tidak perlu ada perbaikan/penyempurnaan dalam penyusunan RPP yang baik dan benar, selanjutnya peneliti memberikan penghargaan/reward kepada semua guru peserta pendampingan karena dari 10 (sepuluh) guru sasaran $100 \%$ sudah memperoleh nilai rata-rata $\geq 80,00$. Penelitian dinayatakan berhasil dan tindakan dihentikan pada siklus II.

\section{PEMBAHASAN}

\section{SIKLUS I}

\section{Tahap Perencanaan}

banyak kendala yang dihadapi dalam tahap perencanaan ini diantaranya adalah dalam penyusunan materi pendampingan, menetapkan skenario dan langkah-langkah pendampingan peneliti, penyusunan instrumen observasi Kepala Sekolah dan instrumen observasi guru, untuk mencari solusi terhadap kendala yang dihadapi peneliti meminta petunjuk dan arahan dari pembimbing. Setelah memperoleh bimbingan dan arahan kendala yang dihadapi peneliti dapat diatasi dengan baik, kegiatan perencanaan pun dapat berjalan sesuai dengan yang direncanakan.

\section{Tahap Pelaksanaan}

Kegiatan nyata dalam pelaksanaan pendampingan dapat dijabarkan sebagai berikut: pada saat menyampaikan materi tentang tata cara penyusunan RPP yang baik dan benar mengalami kendala yang disebabkan peneliti masih kekurangan sumber/buku literatur, sehingga berdampak tertundanya dalam penyusunan, solusi yang dilakukan peneliti mencari beberapa buku literatur terkait dengan tata cara penyusunan RPP termasuk mencari di internet, akhirnya 
materi pendampingan dapat tersusun dengan baik.

Dalam pelaksanaan bimbingan pada saat peserta pendampingan melakukan diskusi/kerjasama dalam kelompok, peneliti berkeliling memberikan bimbingan dan solusi terhadap peserta yang mengalami kesulitan. Pada kegiatan ini peneliti tidak mengalami hambatan/permasalahan artinya berjalan sesuai dengan rencana.

\section{Tahap Observasi/Pengumpulan Data}

Hasil perolehan skor/nilai selama pendampingan pada siklus I peneliti memperoleh skor rata-rata $(3,30)$ dari indikator keberhasilan yang direncanakan yaitu $\geq 4,0$. Ini artinya peneliti masih belum berhasil membimbing 10 (sepuluh) guru peserta pendampingan. Perolehan skor ratarata aktifitas peserta pendampingan pada siklus I yaitu $(3,10)$ dari indikator keberhasilan $(\geq 4,0)$. Artinya bahwa selama pendampingan klasikal maupun pendampingan individual peserta masih belum fokus, dan belum memahami secara mendetail akan arti dan makna pendampingan. Perolehan hasil ini akan terus di optimalkan pada pelaksanaan pendampingan pada siklus berikutnya.

Perolehan nilai rata-rata hasil kerja guru dalam penyusunan RPP yang baik dan benar secara individual memperoleh ratarata $(69,37)$ dari indikator keberhasilan $\geq$ 80,0 (kategori baik). Dari 10 (sepuluh) guru peserta pendampingan pada siklus I belum ada satu guru pun yang dinyatakan memperoleh nilai rata-rata $\geq 80,00$. Ini artinya pada siklus I presentasi pencapaian hasil kerja individual masih 0, dalam arti belum ada yang tuntas sesuai indikator yang telah ditetapkan. Pada kegiatan siklus berikutnya peneliti harus mampu memotivasi peserta pendampingan dalam upaya mencapai indikator keberhasilan sebagai dampak nyata dari hasil pendampingan.

\section{Tahap Refleksi}

Perolehan skor rata-rata hasil observasi Kepala Sekolah selama proses pendampingan baru memperoleh skor ratarata $(3,30)$, sementara perolehan hasil observasi peserta pendampingan sebagai aktifitas peserta selama pendampingan baru memperoleh skor rata-rata $(3,10)$, dan nilai rata-rata hasil penyusunan RPP yang baik dan benar baru mencapai nilai rata-rata $(69,37)$. Dari perolehan hasil dimaksud peneliti merenung mencari faktor kendala dan penyebab sehingga hasil masil belum optimal. Dari hasil renungan itu akhirnya peneliti menemukan solusi untuk dapat dilaksanakan pada kegiatan pendampingan siklus berikutnya.

\section{SIKLUS II}

\section{Tahap Perencanaan}

Kesalahan-kesalahan yang terjadi pada siklus I sudah diperbaiki pada siklus II, sehingga pada tahapan ini peneliti bisa melakukan dengan baik. Kegiatan pada tahap perencanaan ini meliputi; 1) penyempurnaan penyusunan materi pendampingan, 2) perbaikan skenario/strategi/ langkah-langkah pendampingan yang mengarah kepada peserta aktif, 3) menetapkan instrumen observasi Kepala Sekolah dan instrumen observasi guru, 4) menentukan jadwal kegiatan dan menetapkan pedoman analisa data hasil observasi dan hasil kerja individual.

\section{Tahap Pelaksanaan}

Pada tahapan ini, peneliti terlebih dahulu melakukan refleksi atas capaian hasil yang diperoleh pada siklus I. Kendalakendala dan permasalahan yang terjadi dibahas sampai semua peserta pendampingan memahami dan menyadari akan kekurangan, kesalahan dan hal-hal yang bersifat krusial dapat dipecahkan pada saat kegiatan refleksi.

\section{Tahap Observasi}

Pada siklus II perolehan skor ratarata hasil observasi Kepala Sekolah adalah $(4,30)$ dari indikator keberhasilan $\geq 4,00$, ini 
artinya menunjukkan peningkatan yang sangat signifikan bila dibandingkan dengan perolehan hasil pada siklus I. Skor rata-rata hasil observasi guru yaitu aktifitas selama pendampingan dalam forum MGMP memperoleh skor rata-rata $(4,20)$ dari indikator keberhasilan $\geq 4,00$. Dari hasil ini nampak nyata bahwa aktifitas peserta pendampingan pada siklus II mengalami peningkatan yang sangat tajam karena sudah mampu melampaui indikator keberhasilan yang telah ditetapkan. Nilai rata-rata hasil kerja individual dalam penyusunan RPP yang baik dan benar yakni $(86,29)$ dari indikator keberhasilan $(\geq 80,00)$.

\section{Tahap Refleksi}

Berdasarkan hasil akhir perolehan skor rata-rata observasi Kepala Sekolah dan observasi guru serta hasil kerja individual penyusunan RPP yang baik dan benar semuanya telah melampaui indikator keberhasilan maka dapat disimpulkan bahwa: 1) upaya untuk menyempurnakan materi pendampingan dinyatakan berhasil, 2) pelaksanaan untuk memperbaiki strategi penyampaian materi tata cara penyusunan RPP dan strategi pendampingan telah mampu meningkatkan motivasi dan kinerja guru sehingga perolehan hasil yang diharapkan dapat tercapai, 3) upaya untuk mengoptimalkan pelaksanaan pendampingan individual telah membawa dampak positif terhadap perolehan hasil dalam penyusunan RPP yang baik dan benar.

Karena semua indikator keberhasilan telah tercapai maka penelitian tindakan sekolah dihentikan pada siklus II dan dinyatakan berhasil memotivasi guru untuk lebih bergairah dan lebih bersemangat dalam upaya penyusunan RPP yang baik dan benar. Penelitian Tindakan Sekolah dengan judul "Meningkatkan Kompetensi guru dalam penyusunan RPP Yang Baik Dan Benar Melalui Pendampingan Berbasis MGMP Semester ganjil Tahun Pelajaran 2017/2018 di SMP Negeri 1 Ambalawi", dinyatakan "BERHASIL"

\section{KESIMPULAN}

Perolehan data selama penelitian dapat dipaparkan sebagai berikut:

\begin{tabular}{|c|c|c|c|c|c|c|}
\hline & \multirow{2}{*}{ Jenis Keggiatan } & \multirow{2}{*}{$\begin{array}{c}\text { Indikator } \\
\text { Keberhasilan }\end{array}$} & \multicolumn{2}{|c|}{ Perolehan } & \multirow{2}{*}{ Peningkatan } & \multirow{2}{*}{ Ket } \\
\hline & & & Siklus I & Siklus II & & \\
\hline & $\begin{array}{l}\text { Hasil Observasi } \\
\text { Kepala Madrasah }\end{array}$ & $\geq 4,00$ & 3,30 & 4,30 & 1,00 & Tuntas \\
\hline & Hasil Observasi Guru & $\geq 4,00$ & 3,10 & 4,20 & 1,10 & Tuntas \\
\hline & Hasil Kerja Individual & $>80,00$ & 69,37 & 86,29 & 16,92 & Tuntas \\
\hline
\end{tabular}

Pelaksanaan pendampingan berbasis MGMP sangat efektif untuk meningkatkan kompetensi guru dalam penyusunan RPP yang baik dan benar bagi guru sasaran 10 (sepuluh) guru SMP Negeri 1 Ambalawi dalam penyusunan RPP yang baik dan benar. Hal ini dibuktikan meningkatnya perolehan hasil observasi dan hasil kerja individual dari siklus I ke siklus II. Penelitian tindakan sekolah (PTS) ini dinyatakan berhasil dan dihentikan pada siklus II.

\section{SARAN}

Disarankan kepada rekan Kepala Sekolah lain untuk melakukan pendampingan dengan semua guru mata pelajaran dibawah binaan pada sekolah masing-masing dalam upaya meningkatkan kompetensinya khususnya dalam penyusunan RPP yang baik dan benar yang bisa diterapkan dalam proses pembelajaran di kelas senyatanya. Dampak yang diharapkan yaitu meningkatnya kualitas/mutu peserta didik di sekolah binaan melalui proses pembelajaran yang dilandasi dengan penyusunan RPP yang baik dan benar.

Kepada seluruh guru SMP Negeri 1 Ambalawi disarankan untuk membiasakan melakukan musyawarah bersama dalam forum MGMP mata pelajaran yang diampunya, khususnya dalam penyusunan RPP yang baik dan benar, sehingga berdampak meningkatnya kompetensi guru dalam proses pembelajaran di kelas senyatanya dan pada gilirannya prestasi belajar peserta didik dapat ditingkatkan. 
DAFTAR PUSTAKA

Anonim, 2016, Definisi Pendampingan, dalam

https://kamuspsikososial.wordpress.com Itag/definisi-pendampingan/, diakses tanggal 10 Maret 2016 Pukul 13.40 Wita

Anonim, 2016, Kompetensi Guru, dalam https://karyono1993.wordpress.com/the sis/kompetensi-guru/, diakses tanggal 11 Maret 2016 Pukul 11.00 wita

Anonim, 2016, Memberdayakan MGMP, dalam

http://edukasi.kompasiana.com/2012/05

/15/memberdayakan-mgmp/, diakses 15

Maret 2016 Pukul 16.50 Wita

Anonim, 2016, mgmp-musyawarah-gurumatapelajaran, dalam http://melshandyohayo.blogspot.com/2012/06/mgmpmusyawarah-guru-matapelajaran.html, diakses Tanggal 15 Maret 2016 Pukul 16.50 Wita.

Anonim, 2016, Pengertian Kompetensi dan Kompetensi Guru, dalam https://mujibjee.wordpress.com/2010/01 111/pengertian-kompetensi-dankompetensi-guru/, di akses 15 Maret 2016 Pukul 12.45 wita

Anonim, 2016, Pengertian Pendampingan, dalam http://www.bintans.web.id/2010/12/pengertian-

pendampingan.html, diakses tanggal 10 Maret 2016 Pukul 13.40 Wita

Kementrian Pendidikan Nasional, 2010, Kepemimpinan Pembelajaran, Dirjen PMPTK

Keputusan Mentri Pendidikan Nasional No. 16 Tahun 2007, Standar Kualifikasi Akademik dan Kompetensi Guru.

Nana Sujana, 2009, Pendidikan Tingkat KePenelitian Konsep Dan Aplikasinya Bagi Peneliti Sekolah, Jakarta: LPP Bina Mitra.

Peraturan Pemerintah No. 19 tahun 2005 tentang Standar Nasional Pendidikan

Purnadi Pungki, M.W., 2009, KompetensiFaktor Kunci Keberhasilan, dalam http://vibizconsulting.com. Diakses tanggal 11 Agustus 2015 pukul 19.35 wita

Suharjono, 2009, Melaksanakan Sekolah Sebagai Kegiatan Penelitian Tindakan Sekolah Sebagai Kegiatan Pengembangan Profesi Penelitia Sekolah, Jakarta: Bumi Aksara.

Suharjono, 2012, Publikasi Ilmiah Dalam Kegiatan Pengembangan Keprofesian Berkelanjutan Bagi Guru, Jakarta: Cakrawala Indonesia.

Syahrir, S. (2010). Metodologi Pembelajaran Matematika. Yogyakarta: Naufan Pustaka.

Syahrir, S. P. (2012). Pengaruh Pembelajaran Kooperatif Tipe Jigsaw dan Teams Game Turnamen (TGT) terhadap Motivasi Belajar dan Keterampilan Matematika Siswa SMP (Studi eksperimen di SMP Darul Hikmah Mataram). Kontribusi Pendidikan Matematika dan Matematika dalam Membangun Karakter Guru dan Siswa.

Undang-Undang Republik Indonesia, No. 14 Tahun 2005 , Guru dan Dosen Daftar Pustaka

Winsolu, 2009, Pengertian Kompetensi, dalam

http://my.opera.com/winsolu/blog/penge rtian-kompetensi Diakses tanggal 20 Maret 2016 pukul 19.35 wita. 